\title{
DUVERGER'S LAW AND THE SIZE OF THE INDIAN PARTY SYSTEM
}

\author{
Rekha Diwakar
}

\begin{abstract}
Duverger's law postulates that single-member plurality electoral systems lead to two-party systems. Existing scholarship regards India as an exception to this law at national level, but not at district level. This study tests the latter hypothesis through analysis of a comprehensive dataset covering Indian parliamentary elections in the period 1952-2004. The results show that a large number of Indian districts do not conform to the Duvergerian norm of two-party competition, and that there is no consistent movement towards the Duvergerian equilibrium. Furthermore, inter-region and inter-state variations in the size of district-level party systems make it difficult to generalize about the application of Duverger's law to the Indian case. The study concludes that a narrow focus on electoral rules is inadequate, and that a more comprehensive set of explanatory variables is needed to explain the size of the Indian party system even at the district level.
\end{abstract}

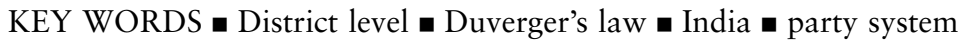

\section{Introduction}

In the literature on the size of the party system, considerable attention has been given to the effects of electoral rules, particularly those governing politics in single-member plurality systems (SMPS). This interest follows Duverger's (1954: 217) argument that 'the simple-majority single-ballot system favours the two-party system'. Over time, this proposition has taken the shape of a law, famously known as Duverger's law. However, in empirical analysis of this law the examination of electoral data has often been overlooked, and for the most part the focus has been at the national level. India follows SMPS, but has many parties (not just two), especially at the national and state level, which is a situation that has led to many scholars treating India as an exception to Duverger's law. Others, however, have 
argued that the Indian party system at district level follows Duverger's law, and is therefore not a correct counterexample. ${ }^{1}$ While there has been some work addressing the question as to why India is an exception, the main focus has been on the national party system. In my study, in contrast, I use a comprehensive dataset to test the applicability of Duverger's law in the district-level party system in India. I find that a large number of Indian districts do not conform to the Duvergerian two-party norm, and that many elections involve competition between many parties and candidates.

The structure of this article is as follows: first, a review of the literature on Duverger's law, followed by a summary of the existing research on application of the law to the Indian party system; next, an empirical analysis of the size of the Indian party system at district level during the period 1952-2004 undertaken using alternative methods, followed by some concluding remarks. ${ }^{2}$

\section{Duverger's Law - Theoretical Framework}

Duverger's law has been criticized because some countries with SMPS have more than two parties at the national level. Canada and India are two prominent exceptions that have been highlighted in the literature; it has been argued that the law does not explain the number of parties. However, it has been pointed out by many scholars that Duverger's law applies at the district level but not at the national or regional level (Chhibber and Kollman, 1998, 2004; Cox, 1997; Gaines, 1999; Sartori, 1986; Wildavsky, 1959). A good starting point for analysing Duverger's law is therefore by examining the underlying reasons for the effect of electoral rules on the size of the party system, and whether these should apply uniformly at the national, region and district levels.

Duverger (1954) put forward mechanical and psychological effects of the institutions, particularly the electoral rules that reduce the number of parties to two in an SMPS. The mechanical effect deals with how votes are translated into seats, and how a party can win a high proportion of votes in a district but still fail to win the seat. When aggregated at the national level, this disproportionality can result in a party winning a large share of the vote but only a small number of seats in the legislature. The psychological effect, on the other hand, concerns how electoral rules influence the aggregation of votes. This is based on the tendency of voters, political leaders and donors to abandon their preferred parties in favour of less preferred parties that have a better chance of winning. And, over time, the party system is expected to move towards some sort of equilibrium where two parties get all or almost all the votes.

In general, the theoretical models support the arguments put forward by Duverger's law and as Chhibber and Kollman (2004: 38) point out: 'There has yet to be a convincing theoretical demonstration that contradicts the 
claim that strategic voting leads to two parties or candidates winning the votes in single-member districts'. However, there has been debate about the level at which Duverger's law should apply. Although the law as originally formulated relates to the national level, Duverger (1954: 223) himself argues that the 'true effect of the simple-majority system is limited to local bipartism'. The existing models of voter behaviour pay inadequate attention to the issues of aggregation of votes from district to region to national level. Although Riker (1976: 94) views Duverger's law as a prediction about district-level competition, his unit of analysis is the single national district, and his conclusions are based on generalizations rather than empirical analysis. Palfrey's (1989: 71) model describes competition in a single district, but does not discuss how it relates to national party systems. Fey (1997) too, disregards the distinction between competition in multiple districts and competition in a single political unit.

Cox's (1994) analysis does not include aggregation issues when examining national rather than district data and evaluating the application of Duverger's law. His empirical analysis relies on the SF ratio, which is the ratio of votes secured by the second loser in relation to the votes secured by the first loser. He expects values of the SF ratio near 0 to signify Duvergerian equilibrium, and a value of 1 to show non-Duvergerian equilibrium, where voters are unable to coordinate, leaving the two losers nearly tied. This interpretation is not exactly what Duverger's law postulates, however, and as Gaines (1999: 840) demonstrates in taking examples from Canadian elections, SF values do not indicate clearly whether the party system they refer to is multiparty or two-party. I observe similar results for Indian elections, where an $\mathrm{SF}$ ratio close to 1 (signifying a non-Duvergerian equilibrium) is possible in two situations: first, where the winning party secures a large majority of votes, leaving a very small proportion of votes for the other parties, and, second, where many parties share the votes in a closely fought election. ${ }^{3}$

Gaines (1999: 837) argues that if voters estimate the party is likely to win only at the district level, then one could witness a two-party competition at the district level, but not necessarily at the state and national levels. On the other hand, if they estimate party prospects at state and national level, then here too it is unlikely there will be two-party competition at national level. Echoing the same idea, Mueller (2003: 272) points out: 'In a single-member district, one's vote is likely to be wasted if one votes for the fourth strongest party in the district, even if it is on an average the strongest party across the country.' Therefore, the application of Duverger's law has to be qualified where party strengths differ greatly across regions. In extreme situations, there is no linkage between or aggregation of parties at the district and national levels. ${ }^{4}$

Since district is the basic electoral unit where voters vote and parties contest elections, the effect of Duverger's law should be seen most clearly at this level, a view that is supported by Chhibber and Kollman (2004: 32), who argue, 'Properly understood in its modern form, the Law predicts (and 
explains why) two parties will capture all the votes in district-level elections in countries with single-member, simple-plurality rules.' It is against this background that I summarize the existing accounts of India's so-called exceptionalism to Duverger's law in the next section.

\section{The Indian Case}

Early studies on the Indian party system point out that since the number of parties, especially at national level, never converges to two, this is an exception to Duverger's law. Riker (1976, 1982) attempts to explain Congress's winning majority of seats without getting a majority of votes during the 1950s and 1960s by arguing that the Congress Party, as the largest single party, included the ideological median of voters and was the second choice of many voters on both its right and left. Thus, the Congress Party has been a Condorcet winner most of the time, though never achieving an absolute majority of votes. This implies that Duverger's law leads to a two-party system, unless the pattern of ideological cleavage and party fractionalization makes the emergence of a Condorcet winner possible. Riker (1982: 761) reformulates Duverger's law to explain the Canadian counter-example when saying that:

Plurality election rules bring about and maintain two-party competition except in countries where (1) third parties nationally are continually one of two parties locally, and (2) one party in several is almost always the Condorcet winner in elections.

Lijphart (1994) suggests that Riker may have overestimated Congress's dominance even during this phase. He argues that Congress did face strong electoral competition, but owing to its unique position in India's independence movement it dominated the electoral scene, especially in the 1950s and 1960s.

Subsequent explanations of the Indian case focus on social heterogeneity and on the number of issue dimensions. Taagepera and Grofman (1985) argue that Duverger's law is an institutional approach focusing on the nature of the electoral system and district magnitude (number of seats per electoral district) rather than on the nature and extent of social cleavages. They argue that Duverger's law assumes a single issue dimension, that is, a left-right ideological axis only, and show that if the number of issue dimensions is increased, the equilibrium number of parties tends to be the number of issue dimensions plus one. Taagepera and Shugart (1989: 152) attribute India's deviation from Duverger's law to the large number of issue dimensions, but emphasize that much depends on whether the issue dimensions remain salient, and whether they are absorbed by existing parties.

More recent accounts of the application of Duverger's law in the Indian party system include several analyses of sub-national party systems. Sridharan 
(1997) studies the applicability of Duverger's law in the Indian case, using the classification proposed by Sartori (1986: 57), according to which:

A two-party system may be characterized by three traits: (1) over time two parties recurrently and largely outdistance all others, in such a way that (2) each of them is in a position to compete for the absolute majority of seats and may thus reasonably expect to alternate in power; and (3) each of them governs, when in government, alone ... a twoparty format denotes two relevant parties, each of which governs alone regardless of third parties.

Sridharan (1997) argues that the Indian party system at national level was a one-party dominated multiparty system between 1952 and 1971, and since 1977 has become more competitive. Sridharan's (1997: 11-12) key conclusion is that:

Duverger's law certainly seems to hold true in state-level party systems for both state assembly and national elections. ... The rational choice insight about sophisticated and disillusioned voting by both voters and politicians would appear to be the best explanation of erosion of Congress support.

Although Sridharan bases his conclusions on the elections held during the period 1952-96, he does not provide any data or statistics in his article. He relies on Sartori's (1986) criteria of relevant parties, which does not provide an objective measure of the number of parties. Finally, his analysis does not provide specific findings about the district-level party systems in India.

Chhibber and Kollman (1998) report that the effective number of parties at district level in India is around 2.5, while at the national level the number has been much larger. In extending their previous analysis, Chhibber and Kollman (2004) report that a large majority of Indian districts follow Duverger's law. In reaching this conclusion, they use a cutoff of 2.5 'effective number of parties' measured using the method proposed by Laakso and Taagepera (1979). However, their main focus is on the national party systems, and they rely on the 'effective number of parties' measure, which is averaged at the national level for each election-year, while paying limited attention to the inter-election and inter-region variations. Furthermore, their data exclude many smaller Indian states and the 1952 elections. ${ }^{5}$

Thus, an empirical analysis on the size of the Indian party system is either not attempted or is attempted but without a comprehensive dataset. Furthermore, wherever conducted, the analysis has been a static one rather than being based on an election-by-election study. Also noticeable is the absence of systematic study about the application of Duverger's law in the Indian party system at district level. The next section extends the empirical research on Duverger's law using the district-level data from the Indian parliamentary elections. ${ }^{6}$ 


\section{Does the Indian Party System Follow Duverger's Law at District Level?}

This section reports the findings of an empirical analysis of the district-level party systems in India. Recent studies evaluating Duverger's law using district-level electoral data are Gaines (1999) for Canadian elections and Reed (2001) for Italian elections. Gaines (1999: 847) conducts a detailed district-level analysis for Canada, the other so-called exception to Duverger's law, and finds that 'District by district, year after year, Canadian elections are not normally two-party (or two-candidate) events'. Reed (2001: 313), on the other hand, finds that:

If we remember first that electoral system effects occur not at the national but at the district level and second that the effects of any structural change take time to work its way through the system, we find that Duverger's law is not only working in Italy but it is working rapidly and powerfully.

This study uses a traditional measure (effective number of parties) as well as a graphical tool (Nagayama diagram) to study the size of the party system and nature of the party competition in Indian districts.

\section{Measuring the Effective Number of Parties}

At the basic level, the number of parties can be counted by simply adding the number of parties that contest elections. However, this can result in a misleading picture of the size of the party system, and, as Lijphart (1994: 67) points out: 'The assumption in the comparative politics literature has long been that some kind of weighting is necessary.' The present study uses the method proposed by Laakso and Taagepera (1979) to determine the 'effective number of parties' $(N)$. The computation of $N$ is given by equation (1), where $p$ represents the vote-share of the $i$ th party:

$$
N=1 /\left(\Sigma p i^{2}\right)
$$

The $N$ measure is relatively simple. It is widely used in the literature and weighs each party with its share of the vote. ${ }^{7}$ For all the Indian parliamentary elections to the Lower House in the single-member districts, $\mathrm{N}$ is calculated using the vote-share of each party. ${ }^{8}$ Using the vote-shares of all parties to compute $N$ avoids the error of clubbing the share of smaller parties and independents into one single category, a practice sometimes resorted to due to lack of complete data. Taagepera (1997) suggested various methods by which to improve the computation of $N$ when working with incomplete data. However, since this study includes vote-shares of all the parties, no such adjustment is needed. The raw data of vote-share of individual parties are sourced from the Election Commission of India reports and Centre for the Study of Developing Societies (CSDS) data unit. It is a comprehensive dataset covering all 14 parliamentary elections held 
during the period 1952-2004 and all Indian states. The raw data of the vote-share of parties are processed to compute $N$ for the Indian districts using equation (1). In all, there are 7005 data-points representing $N$ at the district level in the parliamentary elections.

\section{Size of the District-Level Party System in the Indian Elections}

Figure 1 plots the histogram of $N$ in the Indian districts for all 14 elections (1952-2004) taken together. The histogram bars are drawn on the basis of the percentage of districts falling within a given frequency interval, while the curve shown represents the kernel density estimates. ${ }^{9}$ The $x$-axis represents $N$, and the $y$-axis the percentage of districts with a particular level of $\mathrm{N}$ and the density.

Figure 1 shows that although there is a concentration of data-points around 2 , there is also a large percentage of elections in the Indian districts that witness competition between more than two parties. ${ }^{10}$ The highest concentration of $N$ is between two and three, and the density curve is a relatively low one peaking at around 18 percent. Furthermore, there are many districts that have more than three parties. Based on this, it could be argued that India does not represent a clear case of Duvergerian equilibrium, and there is a non-trivial percentage of districts where electoral competition is between two or more effective parties. However, as Reed (2001: 314) points out:

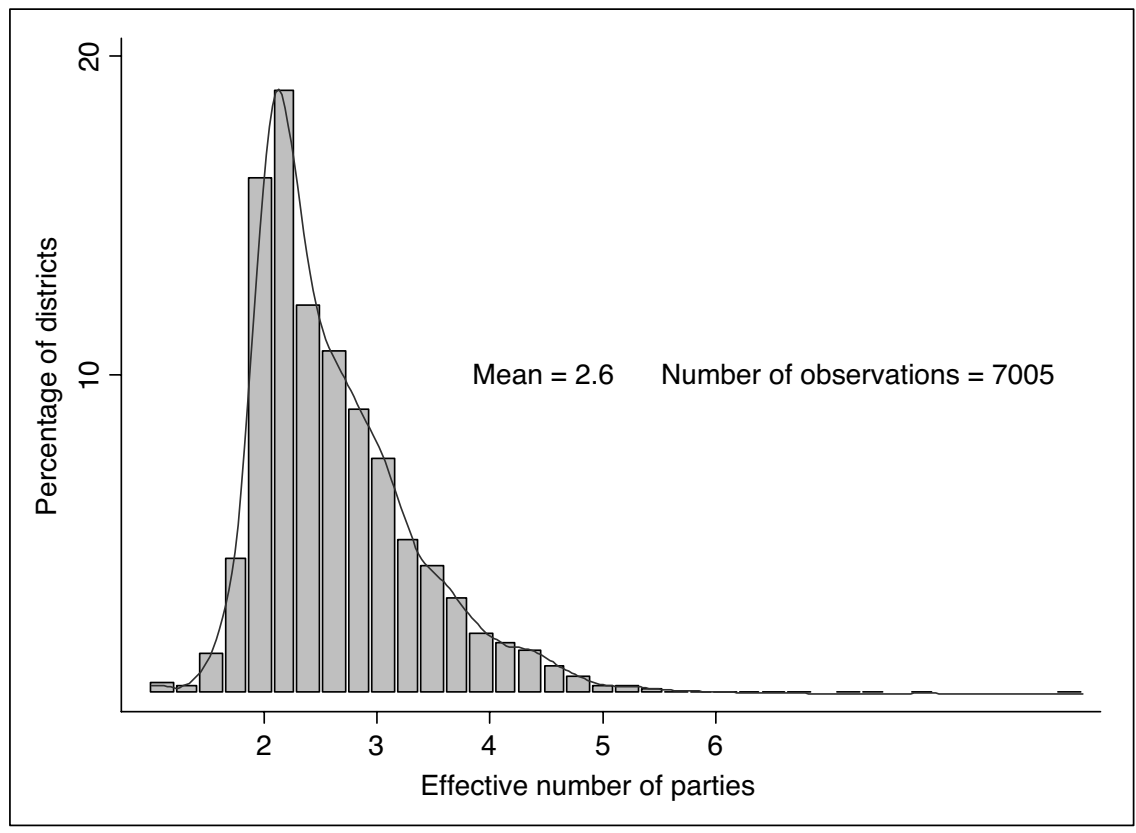

Figure 1. Histogram of effective number of parties (1952-2004) 
[E]quilibrium generalizations, such as Duverger's law, posit tendencies, not certainties. ... Clearly, there is no reason to expect an electoral system to reach equilibrium in the first election. Rather, we should expect trends over time to reflect pressures toward two-party competition.

Furthermore, clubbing all the elections together hides changes in the party system over time, and hence it is important to examine whether elections in India show any movement towards Duvergerian equilibrium or not. Figure 2 shows the histogram and kernel density curve for $N$ in each of the 14 parliamentary elections in India.

Although the shape of the distribution for different elections shown in Figure 2 varies from year to year, the general result is that many districts in India witness competition between more than just two parties. The distribution for the 1952 elections is low and relatively flat, and it can be seen that there is a large percentage of districts where the competition is between more than just two parties. However, since the 1952 elections were the first in India after independence, it is difficult to draw firm conclusions about the nature of party competition from these results alone. The distribution in the 1957 elections is higher and peaks at around two, indicating that a higher percentage of districts witness two-party competition compared to the 1952 elections. This might indicate a movement towards a Duvergerian equilibrium. However, the shape of the 1957 distribution also shows a long right tail indicating the districts with more than two parties in competition. The 1962 elections show a distribution with a lower peak than in 1957, and one that skews more sharply towards the right, signifying multipartism in a large number of districts. The distribution for the 1967 elections is remarkably similar to that of 1962 , which is low, and with a long right tail. The 1971 elections show a reversed trend, where the distribution becomes narrower, peaks at around two, and most of the districts fall within the range two to three. The 1977 elections seem to represent a move towards a Duvergerian equilibrium, where a much larger percentage of the districts witness competition between two parties, and the distribution is narrow and relatively high. The next three elections (in 1980, 1984 and 1989), however, do not produce such extreme results, even though the distribution is generally narrow with a heavy concentration of data-points around 2.5. The question is whether elections in the 1970s and to some extent in the 1980s reflect a consistent movement towards a two-party norm. The subsequent elections in the 1990s and in 2004, however, disprove this hypothesis, and the distributions of $N$ during this period are more evenly spread with a long right tail. It is clear from this discussion that Indian elections have not consistently produced a two-party system at the district level. To provide further evidence, Table 1 gives precise distributions of $N$ in the Indian districts by election, dividing them into four groups. It also provides the mean $N$ and number of districts for each election year.

It can be seen from Table 1 that for all the elections taken together, only 16 percent of the districts have two or fewer than two effective parties, and 

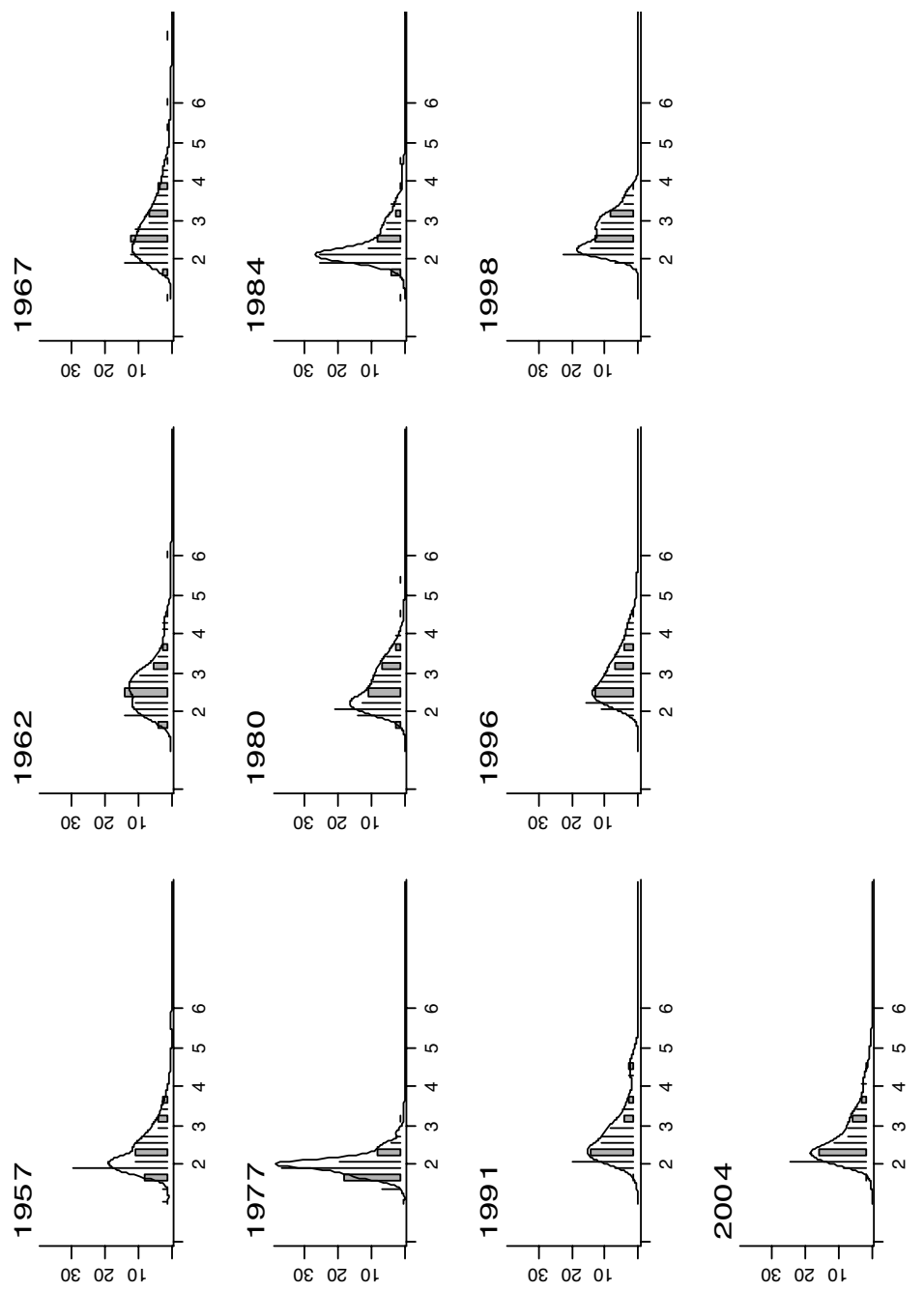

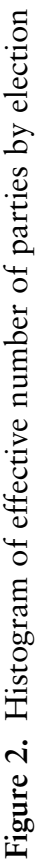
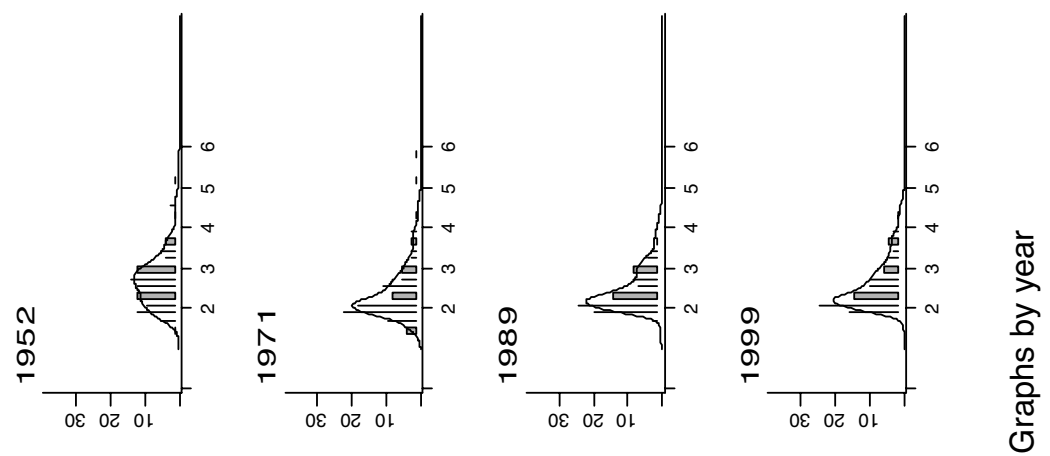

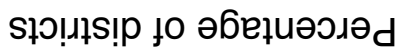


Table 1. Distribution of effective number of parties by election

\begin{tabular}{lllllll}
\hline Election & $\begin{array}{l}\text { Less than or } \\
\text { equal to } 2 \\
\text { year }\end{array}$ & $\begin{array}{l}2-2.5 \\
\%\end{array}$ & $\begin{array}{l}2.5-3 \\
\%\end{array}$ & $\begin{array}{c}>3 \\
\%\end{array}$ & Mean & $\begin{array}{l}\text { No. of } \\
\text { Districts }\end{array}$ \\
\hline 1952 & 19 & 22 & 30 & 29 & 2.73 & 310 \\
1957 & 41 & 23 & 20 & 15 & 2.39 & 312 \\
1962 & 18 & 23 & 30 & 29 & 2.77 & 494 \\
1967 & 15 & 24 & 25 & 36 & 2.92 & 520 \\
1971 & 28 & 36 & 19 & 17 & 2.45 & 518 \\
1977 & 51 & 40 & 8 & 2 & 2.05 & 542 \\
1980 & 9 & 40 & 23 & 28 & 2.67 & 529 \\
1984 & 18 & 50 & 17 & 15 & 2.43 & 542 \\
1989 & 13 & 50 & 18 & 19 & 2.52 & 529 \\
1991 & 7 & 37 & 25 & 31 & 2.86 & 537 \\
1996 & 1 & 29 & 27 & 43 & 3.05 & 543 \\
1998 & 3 & 40 & 29 & 27 & 2.69 & 543 \\
1999 & 6 & 48 & 22 & 40 & 2.64 & 543 \\
2004 & 4 & 45 & 21 & 30 & 2.76 & 543 \\
All elections & 16 & 37 & 22 & 25 & 2.64 & 7005 \\
\hline
\end{tabular}

even after taking a cutoff of 2.5, 47 percent of the districts do not follow Duverger's law. Furthermore, a sizeable 25 percent of districts have more than three parties in competition. Only in 1977 is the Indian party system close to following Duverger's law, where 51 percent of the districts have two or fewer than two, and 91 percent of districts have less than 2.5, effective parties. ${ }^{11}$ For all the other elections, the majority of districts have more than two competing parties; a non-trivial percentage of districts have more than 2.5 and even three effective parties. Elections held in the 1990s and 2004, in particular, have witnessed the percentage of districts with fewer than two effective parties fall well below 10, while the percentage of more competitive districts has increased manifold. For example, in 1991, 1996, 1998, 1999 and 2004 the percentages of districts with more than three parties were 31, 43, 27, 40 and 30, respectively (average of 34 percent during this period). Similar trends are indicated from the mean values of parties listed in Table 1 . The average $N$ for all the elections taken together is 2.64 ; only in 1977 does the average $N$ clearly represent a two-party competition. Furthermore, in 10 out of the total of 14 elections, the average $N$ is greater than 2.5. The distribution of parties and the average statistics are consistent with the visual trends seen in Figure 2. For example, the 1970s witnessed fewer effective parties, while in the 1990s there was a movement towards competition between many parties.

Thus, analysis of the distribution of $N$ in the various Indian elections shows that a two-party system is not the rule in the Indian districts, and a large number of districts witness competition between many parties. Furthermore, 
movements towards the Duvergerian equilibrium have been frequently interrupted, with elections in the 1990s witnessing an increase in $N$ in Indian districts.

\section{Inter-region and Inter-state Variations}

My analysis of elections so far does not recognize that size of party systems varies across Indian regions and states. Studying inter-region variation in the size of the party system in Indian districts is especially important for a country of India's size and heterogeneity. Hindi is the most widely spoken language in India, and all Hindi-speaking states are included in one region - the Hindi belt - which includes some of the largest states in India, both in population and size. The four regions categorized on the basis of geography are South, West, East and North East regions. Finally, non-Hindispeaking states in North India are categorized within the North region. My categorization of Indian regions is consistent with that of Rudolph and Rudolph (1987). ${ }^{12}$ Table 2 gives distribution and mean values of the effective number of parties in Indian regions as defined above for all elections taken together.

Table 2 reveals regional patterns in the distribution of $N$. The Hindi belt is a clear exception to Duverger's law, with 61 percent of districts having more than 2.5 parties, and as many as 40 percent having more than three parties in competition. Since this region includes the maximum (42 percent during 1952-2004) number of electoral districts in India, its deviation from the two-party norm cannot be dismissed simply as an aberration. The North and the North East regions also have a relatively large percentage of districts with more than 2.5 and 3 parties. The situation in the other three regions, i.e. West, East and South, too, shows that a sizeable percentage of districts have more than 2.5 parties, although the deviation from Duverger's law for these regions is not as clear as in the Hindi belt. Table 2 also indicates that average $N$ in all Indian regions except the West and South is above 2.5, and

Table 2. Distribution of effective number of parties by region (1952-2004)

\begin{tabular}{|c|c|c|c|c|c|c|c|}
\hline Regions & $\begin{array}{l}\text { Less than or } \\
\text { equal to } 2 \\
\%\end{array}$ & $\begin{array}{l}2-2.5 \\
\%\end{array}$ & $\begin{array}{l}2.5-3 \\
\%\end{array}$ & $\begin{array}{l}>3 \\
\%\end{array}$ & Mean & $\begin{array}{l}\text { No. of } \\
\text { Districts }\end{array}$ & $\begin{array}{l}\% \text { of } \\
\text { total }\end{array}$ \\
\hline Hindi Belt & 12 & 27 & 21 & 40 & 2.90 & 2943 & 42 \\
\hline South & 21 & 47 & 22 & 10 & 2.38 & 1736 & 25 \\
\hline West & 20 & 46 & 22 & 12 & 2.40 & 999 & 14 \\
\hline East & 14 & 41 & 28 & 16 & 2.55 & 968 & 14 \\
\hline North & 12 & 34 & 27 & 27 & 2.71 & 241 & 3 \\
\hline North East & 28 & 29 & 15 & 28 & 2.70 & 118 & 2 \\
\hline Total & 16 & 37 & 22 & 25 & 2.64 & 7005 & 100 \\
\hline
\end{tabular}


for the largest region, the Hindi belt, it is 2.9 , signalling a deviation from the prediction of Duverger's law.

Figure 3 shows the histogram of $N$ in two large states in the Hindi belt: Uttar Pradesh and Bihar. It can be seen that neither of these states follows Duverger's law. In Uttar Pradesh, which has the highest number of electoral districts in India (15 percent in the most recent elections), most of the distribution of $N$ falls beyond 3, with the average during 1952-2004 being 3.2, and during the last five elections (1991-2004) being as high as 3.7. Similarly, in Bihar a substantial proportion of observations lie beyond 2.5 and a sizeable proportion beyond three parties, with the average being 2.9.

My data reveal that there are significant variations in the size of party systems within each region signifying inter-state differences. This is not unexpected because of the heterogeneity of Indian states, and also because parties fight elections on a state-by-state basis. Thus, not only are there large inter-region differences in the size of party systems, there are also large inter-state differences, and many Indian states (for example, Uttar Pradesh and Bihar) do not represent typical two-party competition, as predicted by Duverger's law. This finding contrasts with existing scholarship on the Indian party systems at district level (for example, Chhibber and Kollman, 2004: 52 ). In addition, it implies that it is difficult and possibly inappropriate to make generalizations about the applicability of Duverger's law in the Indian

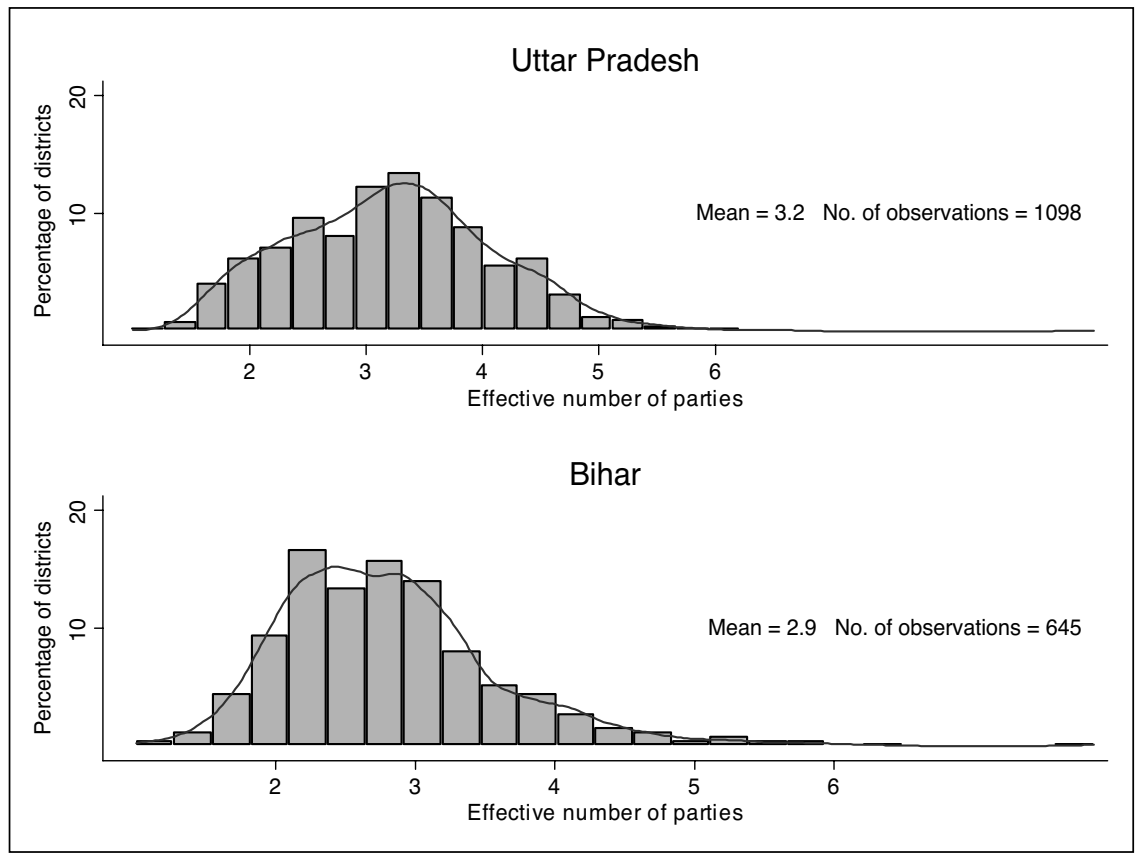

Figure 3. Effective number of parties in Uttar Pradesh and Bihar 1952-2004 
case, and that conclusions based on average $N$ for the country as a whole are misleading.

\section{Trends at the Individual District Level}

The analysis so far has focused on the aggregate measures of district-level $N$, and has not dealt with changes in $N$ for an individual district. Such an analysis is important, because it will reveal whether or not the individual districts conform to the Duvergerian equilibrium between different elections irrespective of the trends of $N$ at an aggregate level. To determine the interelection trends, a paired $t$-test is done on the difference in $N$ for each district between two successive elections. ${ }^{13}$ To check the robustness of the results, a regression model is also specified, taking $N$ at the district level as the dependent variable, and the time (election year) as the independent variable. Following Gaines (1999) and Baltagi (1995), the following fixed-effects model is specified:

$$
N_{i t}=\alpha_{i}+\eta_{t}+\varepsilon_{i t}
$$

In equation (2), $i$ represents an individual district and $t$ the time variable representing a particular election year. The intercept $\alpha_{i}$ represents the normal $N$ for an individual district, while $\eta_{t}$ represents the time trend for a particular election year. Thus, if the dataset includes two successive election years, the coefficient of $\eta_{t}$ will reflect the inter-election movement in $N$, controlling for the differences in the individual districts (through a district-level intercept). Thus, while a negative coefficient of $\eta_{t}$ reflects a movement towards Duvergerian equilibrium, a positive coefficient represents no such trend between successive elections. The results of both the paired $t$-test and the regression are given in Table 3. For the paired comparison, results include mean difference in $N$ between two successive elections and the $t$ statistics for this mean difference. For the regression, the $t$ statistic for the time trend (variable $\eta_{t}$ ) is also shown.

The results in Table 3 show that $t$ statistics of both the mean difference in $N$ and the inter-election time trend are statistically significant. However, their signs are not uniform across the elections. A spell of negative interelection trend has not lasted for more than two election cycles, and so there is no consistent movement towards Duvergerian equilibrium at an individual district level.

The analysis at the individual district level can also identify how many districts consistently deviate from the Duvergerian norm, and how many only show random blips. This analysis is undertaken by studying the trend of $N$ over different elections for an individual district. Two alternative cutoffs for $N$ are defined (2.5 and 3 ) to measure how many districts are over or fluctuate around it and have not stabilized below this cutoff, and how many have just one or two random blips over it. The results from this analysis are given in Table $4 .{ }^{14}$ 
Table 3. Inter-election trends at the district level

\begin{tabular}{lrrrr}
\hline & \multicolumn{2}{c}{ Paired comparison } & & $\begin{array}{l}\text { Fixed effects } \\
\text { regression }\end{array}$ \\
\cline { 2 - 3 } $\begin{array}{l}\text { Election } \\
\text { period }\end{array}$ & $\begin{array}{l}\text { Mean difference } \\
\text { in } \mathrm{N}\end{array}$ & $\begin{array}{l}\text { t statistics of } \\
\text { mean difference }\end{array}$ & $\begin{array}{l}\text { t statistics of } \\
\text { time trend }\end{array}$ \\
\hline $1952-1957$ & -0.7 & -8.1 & -6.9 \\
$1957-1962$ & -0.3 & -3.9 & 8.8 \\
$1962-1967$ & 0.2 & 4.0 & 4.2 \\
$1967-1971$ & -0.5 & -10.3 & -10.3 \\
$1971-1977$ & -0.4 & -11.9 & -11.8 \\
$1977-1980$ & 0.6 & 19.7 & 19.8 \\
$1980-1984$ & -0.3 & -11.4 & -11.8 \\
$1984-1989$ & 0.1 & 4.3 & 4.3 \\
$1989-1991$ & 0.3 & 9.4 & 9.6 \\
$1991-1996$ & 0.2 & 5.4 & 5.3 \\
$1996-1998$ & -0.4 & -11.4 & -11.5 \\
$1998-1999$ & -0.1 & -1.9 & -2.0 \\
$1999-2004$ & 0.1 & 4.2 & 4.5 \\
\hline
\end{tabular}

Table 4 indicates that for a substantial 49 percent of districts, $N$ is consistently over or has fluctuated around the cutoff of 2.5, representing deviation from Duverger's law. Even for a cutoff of three, a non-trivial 24 percent of the districts consistently witness competition among many rather than just two parties. Furthermore, a large proportion of districts show occasional blips over both the cutoffs, and only a relatively small percentage ( 7 and 18 , respectively) have stabilized around a Duvergerian equilibrium. Thus, even at a micro-level there is no unequivocal evidence that district-level party systems in India represent, or are moving towards, bipartisan competition.

Table 4. Effective number of parties - trends at the individual district level (1952-2005)

\begin{tabular}{|c|c|c|c|c|}
\hline & \multicolumn{2}{|c|}{ Cutoff $\mathrm{N}=2.5$} & \multicolumn{2}{|c|}{ Cutoff $\mathrm{N}=3$} \\
\hline & No. of districts & $\%$ & No. of districts & $\%$ \\
\hline $\begin{array}{l}\text { (1) Districts over/fluctuating } \\
\text { around cutoff }\end{array}$ & 261 & 49 & 128 & 24 \\
\hline $\begin{array}{l}\text { (2) Districts below cutoff with } \\
\text { occasional blips over cutoff }\end{array}$ & 235 & 44 & 305 & 57 \\
\hline $\begin{array}{l}\text { (3) Districts stabilized below } \\
\text { cutoff }\end{array}$ & 35 & 7 & 98 & 18 \\
\hline Total & 531 & 100 & 531 & 100 \\
\hline
\end{tabular}




\section{Nagayama Diagrams for the Indian Party System}

When analysing pre-war Japanese elections, Nagayama (1997) plotted the percentage of the vote received by the winning candidate (V1) against the percentage received by the runner-up (V2). He noticed that all the plots took the form of a triangle bound between two lines representing $\mathrm{V} 1-\mathrm{V} 2=0$ and $\mathrm{V} 1+\mathrm{V} 2=1$. The former line segment represents data-points where the winner and runner-up parties have equal vote-shares; the latter line segment includes data-points where no third party receives any votes. Thus, the left corner area of the triangle corresponds to the presence of multiple contestants (since the combined vote-share of the top two parties is less than 100 percent), while the right corner represents single- or two-party dominance. The peak of the triangle reflects two-party competition with limited thirdparty strength. Thus, the Nagayama diagram enables comparison of the electoral outcomes for different elections in terms of the degree of competition between the top two vote-getting parties, and the extent to which smaller parties get a substantial share of votes. The vote-share of the balance parties can be computed by adding V1 and V2 and subtracting the sum from 1. Reed (2001) uses Nagayama diagrams to study the working of Duverger's law in the Italian elections of 1994 and 1996, while Taagepera (2004) illustrates use of the Nagayama diagram for assessing party strength. Figure 4 plots the Nagayama diagrams for elections in the Indian districts.

It can be seen that different periods reflect different types of party competition and distributions of votes among parties. The 1950s' diagram shows a large concentration towards the middle and left of the triangle, signifying competition between many parties. However, there is also a significant number of data-points towards the right side of the triangle, depicting competition between two parties. The concentration of the data-points shifts towards the left in the 1960s, showing a move towards competition between many parties. The 1970s show a reversal, where most of the datapoints stack up on the right-hand side, signifying dominance of one or two parties. In the 1980 s, the data-points seem to be equally divided between the left and right sides, while the 1990s and 2004 see a majority of datapoints moving towards the top left corner, thereby signalling multiparty competition.

Grofman et al. (2004) provide additional labelling of segments of the Nagayama triangle to facilitate visual comparison of multiple diagrams representing different elections or the same election in different regions. They use the parameter $z(0 \leq z \leq 0.50)$ to divide the triangle into eight segments reflecting the relative strengths of first-, second- and third-ranking parties, and draw the 'segmented Nagayama triangle' for the Italian single-member districts using data from the 1994, 1996 and 2001 elections. The various segments of the segmented Nagayama triangle are shown in Figure $5 .{ }^{15}$

The $x$ and $y$ axes in Figure 5 represent the vote-shares of the winner and runner-up party, respectively, and $z$ is taken to equal $0.20 .{ }^{16}$ The area 

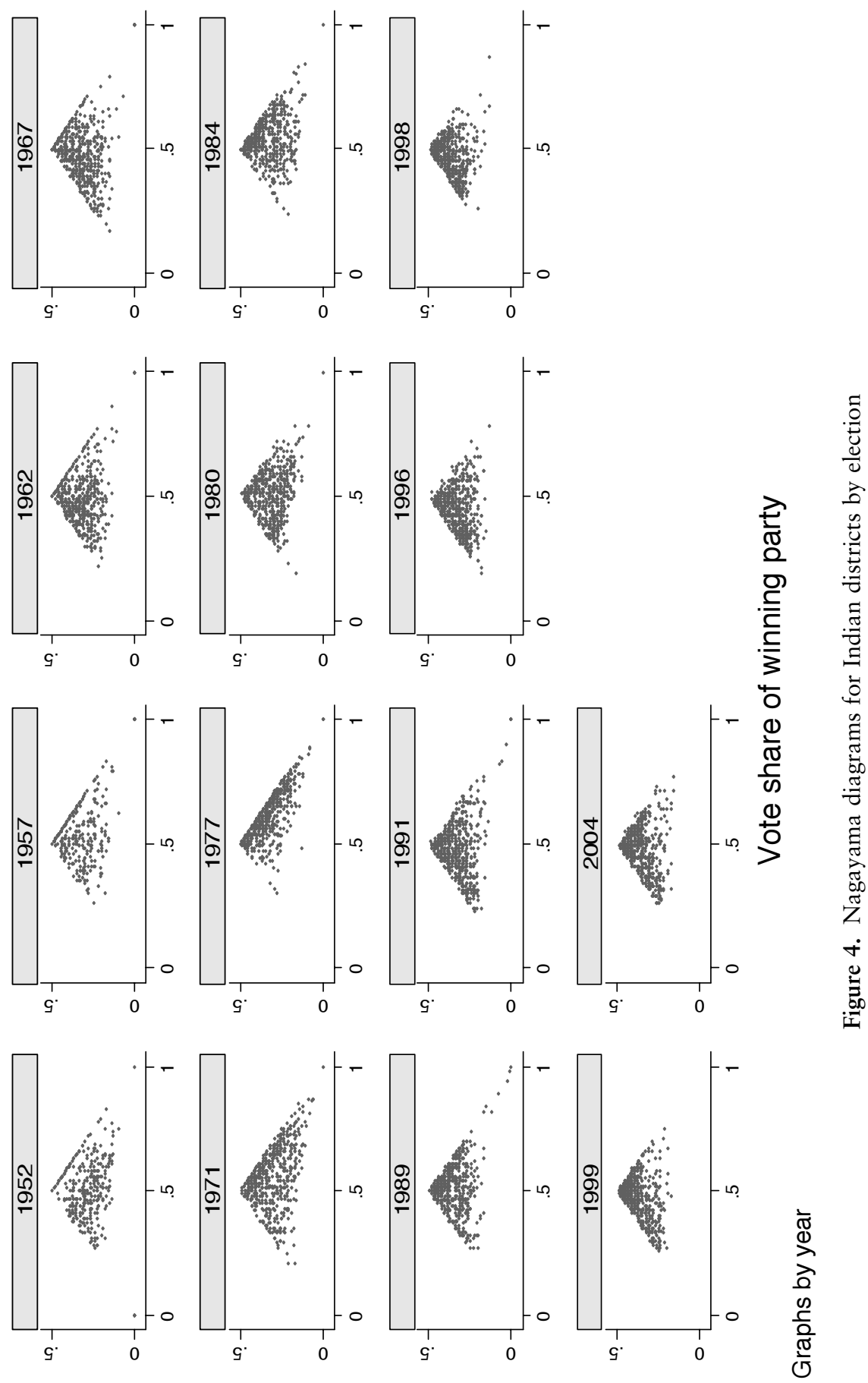

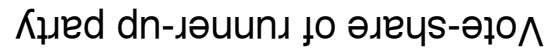




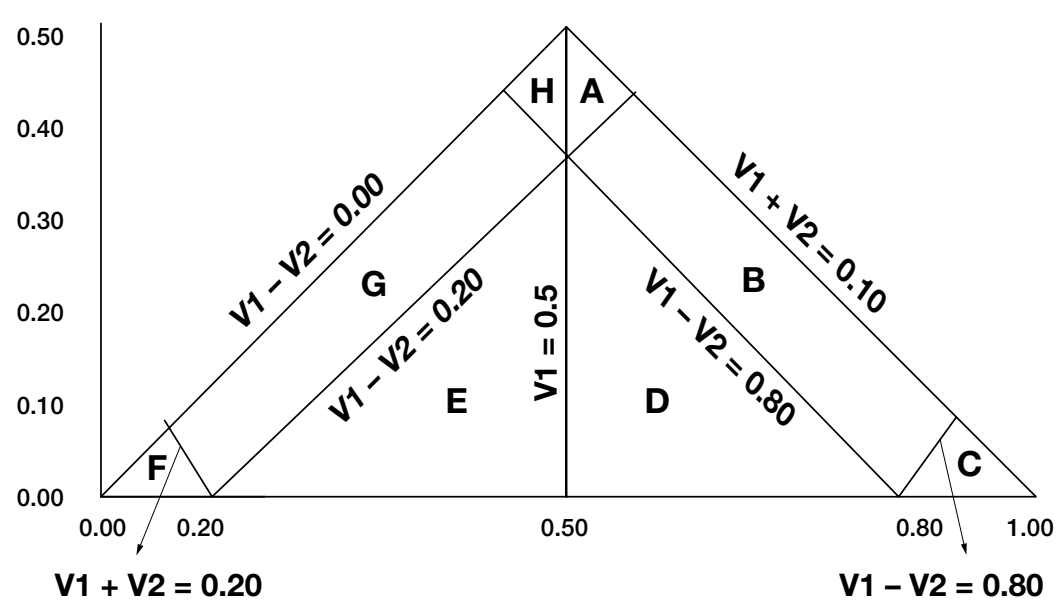

Figure 5. Segmented Nagayama triangle template

Source: Based on Grofman et al. (2004).

representing 'districts with limited third-party strength' lies on or between the line segments defined by $\mathrm{V} 1+\mathrm{V} 2=1-z=0.80$ and $\mathrm{V} 1+\mathrm{V} 2=1$, and is given by $\mathrm{H}+\mathrm{A}+\mathrm{B}+\mathrm{C}$. The area representing 'competitive districts' lies on or between the line segments defined by the lines V1 $-\mathrm{V} 2=0$ and V1 $\mathrm{V} 2=z=0.20$, and is given by $\mathrm{H}+\mathrm{A}+\mathrm{F}+\mathrm{G}$. These two areas overlap, sharing segments $\mathrm{A}$ and $\mathrm{H}$, the combination of which characterizes 'limited minor party strength and political competitiveness among the top two parties'. The sum of segments D and E represents 'neither strong or complete single-party or two-party dominance nor political competitiveness among the top two parties'. The area defined by segment $\mathrm{F}$ lies on or between the line segments defined by the lines $\mathrm{V} 1-\mathrm{V} 2=0$ and $\mathrm{V} 1+\mathrm{V} 2=z=0.20$ and the $x$-axis represents a zone of 'extreme multiparty competition', while the area defined by segment $\mathrm{C}$ alone lies on or between the line segments defined by the lines $\mathrm{V} 1+\mathrm{V} 2=1$ and $\mathrm{V} 1-\mathrm{V} 2=1-z=0.80$ and the $x$-axis represents a zone of 'extreme one-party dominance'. If the area under the Nagayama triangle is normalized to 1 , the areas in each of the eight segments can be shown as a function of $z$ in equations (3)-(5) (Grofman et al., 2004: 277):

$$
\begin{gathered}
A=H=C=F=z^{2} \\
D=E=2 z^{2}-2 z+1 / 2 \\
B=G=-4 z^{2}+2 z
\end{gathered}
$$

The results from the segmented Nagayama diagram for the Indian elections following Grofman et al. (2004) are summarized in Table 5 grouped into decades for brevity and convenience.

The results in Table 5 (top panel) show that most of the districts lie in the $\mathrm{B}, \mathrm{G}$ or $\mathrm{H}$ segments. While B represents one-party or two-party dominance, 
Table 5. Proportions of districts in segmented Nagayama diagram

\begin{tabular}{lllllll}
\hline Period covered & $1950 s$ & $1960 s$ & $1970 s$ & $1980 s$ & $1990 s+$ & $\begin{array}{l}\text { All years } \\
\text { No. of elections }\end{array}$ \\
No. of districts & 622 & 1014 & 1060 & 1600 & 2709 & 7005 \\
\hline Segments & & & & & & \\
A & 0.00 & 0.00 & 0.00 & 0.00 & 0.00 & 0.00 \\
B & 0.45 & 0.32 & 0.72 & 0.51 & 0.31 & 0.43 \\
C & 0.01 & 0.01 & 0.01 & 0.00 & 0.00 & 0.00 \\
D & 0.10 & 0.06 & 0.04 & 0.06 & 0.02 & 0.05 \\
E & 0.07 & 0.06 & 0.03 & 0.05 & 0.03 & 0.04 \\
F & 0.00 & 0.00 & 0.00 & 0.00 & 0.00 & 0.00 \\
G & 0.24 & 0.34 & 0.09 & 0.21 & 0.34 & 0.26 \\
H & 0.12 & 0.21 & 0.11 & 0.17 & 0.30 & 0.21 \\
Total & 1.00 & 1.00 & 1.00 & 1.00 & 1.00 & 1.00 \\
\hline Categories of districts & & & & & & \\
Categories with no & 0.47 & 0.33 & 0.73 & 0.52 & 0.31 & 0.44 \\
substantial third-party & & & & & & \\
strength (A + B + C) & & & & & & \\
Competitive districts & 0.36 & 0.55 & 0.20 & 0.38 & 0.64 & 0.47 \\
(F + G + H) & & & & & & \\
Neither strong or complete & 0.17 & 0.12 & 0.07 & 0.10 & 0.05 & 0.09 \\
single- or two-party & & & & & & \\
dominance nor political & & & & & & \\
competitiveness (D + E) & & & & & & \\
\hline
\end{tabular}

$\mathrm{G}$ represents area with competitive districts. H represents political competitiveness between the top two parties or limited third-party strength. In the 1950 s, 45 percent of the districts are in segment B, signifying single- or two-party dominance, while 24 percent are in segment $G$ and 12 percent in segment $\mathrm{H}$. In the 1960 s, more districts - 34 percent - are in the competitive zone $\mathrm{G}$, while the proportion in segment B declines to 32 percent. Furthermore, the proportion of districts in segment $\mathrm{H}$ increases to 21 percent. Overall, in the 1960s a majority of districts witnessed competition between more than two parties. In the 1970s this process is dramatically reversed, with 72 percent of districts being in segment B showing single- or two-party competition. The 1980s also show a large proportion of districts witnessing competition between two or fewer parties, although the percentage of districts in segment B declines to 51, while districts in the competitive zone $\mathrm{G}$ increase to 21 percent. Elections in the 1990 s and 2004 once again reverse this trend, and only 31 percent of the districts show dominance by two or fewer than two parties.

Table 5 (bottom panel) also provides the proportion of districts in three categories proposed by Grofman et al. (2004: 278), i.e. (1) 'Districts with 
no substantial third-party strength' $(A+B+C),(2)$ 'Competitive districts' $(\mathrm{F}+\mathrm{G}+\mathrm{H})$, and (3) 'Neither strong or complete single-party or two-party dominance nor political competitiveness' $(\mathrm{D}+\mathrm{E}) .{ }^{17}$ The results show that for all the elections taken together, 47 percent of the districts are competitive as defined above, while 44 percent do not have any substantial thirdparty strength, i.e. representing two-party competition, while the balance, 9 percent, do not fall within any of these categories. It is important to note that for five elections held in the 1990s and 2004, 64 percent of the districts are in the competitive category, thus signalling a departure from Duverger's law. Overall, the analysis using the Nagayama diagram, too, supports the overall argument of this study that there is no unqualified support for Duverger's law across Indian districts.

\section{Conclusions}

I have used alternative methods to study the application of Duverger's law to the Indian party system at district level, and have come to three main conclusions. First, there is no unequivocal support for it in Indian districts. While many districts witness competition between two or fewer than two parties, there is a non-trivial number of districts where elections involve competition between many parties. This is similar to Gaines's (1999) finding on the Canadian party system, but in contrast to the existing beliefs and findings about the size of the Indian party system at district level. The last five elections during the period 1991-2004 have seen a move towards a more competitive Indian party system at district level. Furthermore, there is no clear movement towards the Duvergerian equilibrium, and negative inter-election trends have not lasted beyond two electoral cycles.

Second, there are inter-region and inter-state differences in the size of party systems at the district level. In general, districts in the West and South regions have fewer parties and are closer to following Duverger's law, while districts in other regions, especially the Hindi belt, witness competition between many parties. Furthermore, many large Indian states exhibit multipartism rather than the predicted two-party competition.

Finally, the results imply that generalizing about the Indian party system is difficult in light of inter-region, inter-state and inter-temporal variation in the size of the party system. A narrow focus on electoral rules is therefore inadequate; a more comprehensive set of explanatory variables is needed to explain the size of the party system even at district level.

\section{Notes}

1 In India, the electoral district is known as a 'constituency'.

2 My empirical analysis methodology draws on Gaines (1999) and Grofman et al. (2004). 
3 For example, in cases 1-3, one party wins a sizeable majority, while in cases 4-6 elections are closely contested. However, SF values for all these cases are close to 1 , which, according to $\operatorname{Cox}$ (1997), represents a non-Duvergerian equilibrium.

\begin{tabular}{|c|c|c|c|c|c|c|c|c|c|}
\hline \multirow[b]{2}{*}{ Case } & \multirow[b]{2}{*}{ District } & \multirow[b]{2}{*}{ Year } & \multicolumn{6}{|c|}{ Vote-share of parties (\%) } & \multirow[b]{2}{*}{ SF Ratio } \\
\hline & & & 1 & 2 & 3 & 4 & 5 & Bal. & \\
\hline 1. & Rae Barelli & 1984 & 70 & 13 & 11 & 2 & 1 & 3 & 0.91 \\
\hline 2. & Khed & 1991 & 61 & 19 & 17 & 1 & 1 & 1 & 0.90 \\
\hline 3. & Mamupuri & 2004 & 64 & 17 & 15 & 1 & 1 & 2 & 0.91 \\
\hline 4. & Tenali & 1967 & 35 & 25 & 23 & 9 & 7 & 1 & 0.93 \\
\hline 5. & Lakhimpur & 1999 & 34 & 27 & 25 & 2 & 1 & 11 & 0.92 \\
\hline 6. & Aonla & 2004 & 29 & 27 & 27 & 9 & 3 & 5 & 0.97 \\
\hline
\end{tabular}

4 Cox (1997) uses 'linkage', while Chhibber and Kollman (1998, 2004) use 'aggregation' to describe the relationship between the district and national party systems.

5 I do not see any reason for excluding data from single-member districts in the 1952 elections.

6 In a recent work, Chhibber and Murali (2006) use data from state assembly elections in India to study non-random deviations from Duverger's law and attribute these to the influence of federal arrangements.

$7 \mathrm{~N}$ can also be calculated using seat-share rather than vote-share of the $i$ th party. This study focuses on the number of electoral (vote-getting) parties, and therefore uses $N$ based on the vote-share of each party.

8 Some districts in 1952 and 1957 were multi-member. My analysis includes data for single-member districts only.

9 The kernel density curve is a 'smoothed histogram' calculating the density at each point as it moves along the $x$-axis. Throughout this article, the curve drawn through all the histogram charts reflects the kernel density curve.

10 The literature uses different cutoffs for the effective number of parties when evaluating Duvergerian equilibrium. Instead of using a specific cutoff, I attempt to demonstrate that for a non-trivial number of Indian districts the Duvergerian concept of competition between two major parties does not exist.

11 The 1977 elections were held in unusual circumstances after a period of emergency rule, when the entire opposition united against the Congress Party.

12 The states in the six regions are as follows: Hindi belt - Uttar Pradesh, Bihar, Jharkhand, Rajasthan, Uttaranchal, Haryana, Madhya Pradesh, Chhatisgarh, Delhi, Himachal Pradesh; North - Punjab, Chandigarh, Jammu and Kashmir; West - Maharashtra, Gujarat, Goa, Dadra and Nagar Haveli; East - Andaman and Nicobar Island, West Bengal, Assam, Orissa; South - Andhra Pradesh, Kerala, Tamil Nadu, Karnataka, Lakshadweep, Pondicherry; North East Arunachal Pradesh, Manipur, Mizoram, Nagaland, Meghalaya, Sikkim, Tripura.

13 Paired comparison is done for those districts where clear successors/predecessors are available, in order to take account of the reorganization of districts in the 1950s, 1960s and 1970s, and situations where elections were not held (for example, Assam in 1989). 
14 The number of electoral districts in India has varied across the elections, and currently stands at 543. This analysis includes 531 districts which have a sufficient number of observations to identify the trends of $N$ over time.

15 The description of a segmented Nagayama diagram follows Grofman et al. (2004).

16 Grofman et al. (2004: 278 ) point out that $z=0.20$ is a plausible break point, because an 80 percent vote-share for the top two parties can be a reasonable operationalization of the concept of clear two-party dominance.

17 Instead of the overlapping area categories used in Grofman et al. (2004), distinct area segments are used here. Thus, $\mathrm{H}$ and A are included in 'competitive districts' and 'districts with no substantial third-party strength', respectively.

\section{References}

Baltagi, Badi H. (1995) Econometric Analysis of Panel Data. Chichester: Wiley.

Chhibber, Pradeep and Ken Kollman (1998) 'Party Aggregation and the Number of Parties in India and the United States', American Political Science Review 92: 329-42.

Chhibber, Pradeep and Ken Kollman (2004) The Formation of National Party Systems: Federalism and Party Competition in Canada, Great Britain, India and the United States. Princeton, NJ: Princeton University Press.

Chhibber, Pradeep and Geetha Murali (2006) 'Duvergian Dynamics in the Indian States', Party Politics 12(1): 5-34.

Cox, Gary (1994) 'Strategic Voting Equilibria Under the Single Nontransferable Vote', American Political Science Review 88: 608-21.

Cox, Gary (1997) Making Votes Count: Strategic Coordination in the World's Electoral Systems. Cambridge: Cambridge University Press.

Cox, Gary (1999) 'Electoral Rules and Electoral Coordination', Annual Review of Political Science 2: 145-61.

CSDS data unit. Centre for Study of Developing Societies. New Delhi.

Duverger, Maurice (1954) Political Parties. New York: Wiley.

Election Commission of India. Reports on the Parliamentary Elections (various years).

Fey, Mark (1997) 'Stability and Coordination in Duverger's Law: A Formal Model of Preelection Polls and Strategic Voting', American Political Science Review 91: 135-47.

Gaines, Brian (1997) 'Where to Count Parties', Electoral Studies 16: 49-58.

Gaines, Brian (1999) 'Duverger's Law and the Meaning of Canadian Exceptionalism', Comparative Political Studies 32: 835-61.

Gaines, Brian (2000) 'From Duverger to Cox and Beyond', Japanese Journal of Political Science 1: 151-6.

Grofman, Bernard et al. (2004) 'Comparing and Contrasting the Uses of Two Graphical Tools for Displaying Patterns of Multiparty Competition: Nagayama Diagrams and Simplex Representations', Party Politics 10: 273-99.

Laakso, Markku and Rein Taagepera (1979) "Effective" number of Parties: A Measure with Application to Western Europe', Comparative Political Studies 12: 3-27.

Lijphart, Arend (1984) Democracies: Patterns of Majoritarian and Consensus Governments in Twenty-one Countries. New Haven, CT: Yale University Press. 
Lijphart, Arend (1990) 'The Political Consequences of Electoral Laws 1945-85', American Political Science Review 84: 481-96.

Lijphart, Arend (1994) Electoral Systems and Party Systems. Oxford: Oxford University Press.

Mueller, Dennis (2003) Public Choice III. Cambridge: Cambridge University Press.

Nagayama, Masao (1997) 'Shousenkyoku no kako to genzai' ('The Present and Future of Single-Member Districts'). Paper presented at the Annual Conference of the Japan Political Science Association, 4-6 September (cited in Reed, 2001 and Grofman et al., 2004).

Palfrey, Thomas (1989) 'A Mathematical Proof of Duverger's Law', in P. Ordeshook (ed.) Models of Strategic Choice in Politics. Ann Arbor, MI: University of Michigan Press.

Rae, Douglas (1971) The Political Consequences of Electoral Laws. New Haven, CT: Yale University Press.

Reed, Steven (1990) 'Structure and Behavior: Extending Duverger's law to the Japanese Case', British Journal of Political Science 29: 335-56.

Reed, Steven (2001) 'Duverger's Law is Working in Italy', Comparative Political Studies 34: 312-27.

Riker, William (1976) 'The Number of Political Parties', Comparative Political Studies 9: 93-106.

Riker, William (1982) 'The Two-Party System and Duverger's Law: An Essay on the History of Political Science', American Political Science Review 76: 753-66.

Riker, William (1986) The Art of Political Manipulation. New Haven, CT: Yale University Press.

Rudolph, Lloyd and Susanne Rudolph (1987) In Pursuit of Lakshmi: The Political Economy of the Indian State. Chicago, IL: University of Chicago Press.

Sartori, Giovanni (1976) Parties and Party Systems: A Framework for Analysis. Cambridge: Cambridge University Press.

Sartori, Giovanni (1986) 'The Influence of Electoral Systems: Faulty Laws or Faulty Method?' in Bernard Grofman and Arend Lijphart (eds) Electoral Laws and Their Political Consequences. New York: Agathon Press.

Sridharan, E. (1997) 'Duverger's Law and Its Reformulations and the Evolution of the Indian Party System', IRIS India Working Paper. University of Maryland at College Park.

Taagepera, Rein (1997) 'Effective Number of Parties for Incomplete Data', Electoral Studies 16: 145-51.

Taagepera, Rein (2004) 'Extension of the Nagayama Triangle for Visualization of Party Strengths', Party Politics 10: 301-6.

Taagepera, Rein and Bernard Grofman (1985) 'Rethinking Duverger's Law: Predicting the Effective Number of Parties in Plurality and PR Systems - Parties Minus Issues Equals One', European Journal of Political Research 13: 341 -52.

Taagepera, Rein and Matthew Shugart (1989) Seats and Votes: The Effects and Determinants of Electoral Systems. New Haven, CT: Yale University Press.

Taagepera, Rein and Matthew Shugart (1993) 'Predicting the Number of Parties: A Quantitative Model of Duverger's Mechanical Effect', American Political Science Review 87: $455-64$.

Wildavsky, Aron (1959) 'A Methodological Critique of Duverger's Political Parties', Journal of Politics 21: 303-18. 
REKHA DIWAKAR is Lecturer of Research Methods at Goldsmiths College, University of London, and holds a Tutorial Fellowship at the London School of Economics and Political Science.

ADDRESS: Department of Politics, Goldsmiths College, University of London, New Cross, London SE14 6NW, UK. [email: r.diwakar@gold.ac.uk]; Department of Government, London School of Economics and Political Science, Houghton Street, London WC2A 2AE, UK. [email: r.diwakar@lse.ac.uk]

Paper submitted April 2005; accepted for publication February 2006. 